\section{Enzyme Localization in Proteins Separated by Paper Electrophoresis in Human Seminal Plasma}

Several enzymes have been detected in human seminal plasma. This fluid is very rich in glutamic oxalacetic (GOT), glutamic pyruvic (GPT) transaminases 1,2 and $\alpha$-amylase ${ }^{2,3}$ and we therefore found it of interest to report the localization of these enzymes in normal human seminal plasma after separation of proteins by paper electrophoresis.

Materials and Methods. Paper electrophoresis was performed in a Spinco paper electrophoresis apparatus with a veronal buffer ( $\mathrm{pH} 8.6$ and ionic strength 0.05 ), at $4 \mathrm{~mA}$. Complete separation was attained after $16 \mathrm{~h}$.

Amounts of $0.01 \mathrm{ml}$ of seminal plasma were applied to seven strips as opposed to $0.006 \mathrm{ml}$ of human serum applied to one of them. This strip and one of the others were dried and fixed at $100^{\circ} \mathrm{C}$ for $15 \mathrm{~min}$ and stained with $1 \%$ bromphenol blue ${ }^{4}$. The other six strips were not fixed but cut in $1 \mathrm{~cm}$ segments and eluted in buffers for

Localization of enzymes in seminal plasma

\begin{tabular}{|c|c|c|c|}
\hline & $\begin{array}{l}\text { Anvilase } \\
\%\end{array}$ & $\begin{array}{l}\text { GOCT } \\
\%\end{array}$ & $\begin{array}{l}G 1 \% \\
\%\end{array}$ \\
\hline Albumin & 16.3 & & 100 \\
\hline$\alpha-1$ Globulin & 20.1 & & \\
\hline$x-2$ Globulin & 11.8 & 1017 & \\
\hline$\beta$-Globulin & 8.7 & & \\
\hline$y$-Globulin & 26.8 & & \\
\hline O-Fraction (orisin) & 16.33 & & \\
\hline
\end{tabular}

GOT $^{5}$, GPT $^{5}$ and $\alpha$-amylase ${ }^{6}$ determinations. After this, lectures in optical density were plotted against distance in $\mathrm{cm}$ from origin.

Results. Results are presented in the Table and are the average values from 5 determinations in seminal plasma obtained from men with normal samples (after being submitted to several criteria of normality: spermatozoa number, volume of ejaculate, percentual quantity of abnormal and immobile forms, vitality after 12 and $24 \mathrm{~h}$, at $4^{\circ} \mathrm{C}$ and $37^{\circ} \mathrm{C}$ ).

Amylase was localized in every fraction but GOT and GPT were situated in $\alpha-2$ globulin and albumin, respectively.

Résumé. Les transaminases $\alpha$-glutamo-oxaloacétique (GOT) et glutamo-pyruvique (GPT) ont été déterminées dans les protéines du liquide spermatique de l'homme après séparation par électrophorèse sur papier. L'amylase se trouve dans toutes les fractions, mais la GOT et la GPT sont localisées respectivement dans la globuline $\alpha-2$ et l'albumine.

H. POVOA, JR.

du. Copacabana, 540, hio de Janeiro (Brazil), June 19 , 1962.

\footnotetext{
- H. Povoa Jtr. and G. G. Villela, lixper, 76,199 (10mo).

- H. Povoa Jr., J. Bras. Med., in press.

3. ‥ Goldblatt, Biochem. J. 29,1346 (1935).

4 H. CReMer and A. Trselues, Biochem. $Z, 320,273(1950)$.

3 J. J. King, J. med. lab. Technol. 15, 17 (1958).

6). Somogrt, Arch. int. Med. 67, 665 (1941).
}

\section{Effect of Cold Acclimatization on the Succinic Dehydrogenase Activity in the Liver and Brain Tissues of Mice}

Little is known about the cold acclimatization in mammals other than rats. In addition, studies on the effects of the cold acclimatization on tissue metabolism have been confined to skeletal muscles and visceral tissues, as appears from the recent reviews ${ }^{1}$ on this subject. It is a well-established fact that the succinic dehydrogenase activity in the liver tissue of rats increases during the cold acclimatization ${ }^{2}$. The aim of the present experiments was to find out whether this change also occurs in the liver and brain tissues of mice.

Groups of male albino mice were kept for 7 to 12 days at $+5^{\circ} \mathrm{C}$ in a refrigerator. The control males, similar in age and in weight, were kept in the animal room at $+24^{\circ} \mathrm{C}$. Tissue homogenates $(5 \%)$ were prepared from the liver and from the whole brain of decapitated animals in ice-cold buffer. The succinic dehydrogenase

\begin{tabular}{|c|c|c|c|}
\hline \multirow[t]{2}{*}{$\begin{array}{l}\text { Acclimatization } \\
\text { temperature }\end{array}$} & \multicolumn{3}{|c|}{$\begin{array}{l}\text { Succinic dehydrogenase activity (uy reduced } \\
\text { TrC per lag fresh tissue in } 10 \text { miil) }\end{array}$} \\
\hline & Liver & I3rain & \\
\hline $5 \mathrm{C}$ & $3.30 \pm 0.21$ & $0.30 \pm 0.02$ & (14) \\
\hline $24^{\circ} \mathrm{C}$ & $1.92 \pm 0.18$ & $0.32 \pm 0.02$ & (14) \\
\hline
\end{tabular}

activity was measured with the method of KUN and $A_{B O O D}{ }^{3}$. The reaction tubes contained $0.5 \mathrm{ml} 0.2 \mathrm{M}$ Na-succinate, $1 \mathrm{ml}$ tissue homogenate in $0.13 \mathrm{M}$ phosphate buffer ( $\mathrm{pH} 7.4$ ) and $1 \mathrm{ml} 0.1 \%$ triphenyltetrazolium chloride (TTC). The reaction was stopped and the formazan brought into solution by adding $8 \mathrm{ml}$ ethanol. The linearity of the concentration of red formazan in relation to the incubation time (at $38^{\circ} \mathrm{C}$ ) was checked. The incubation times chosen were $10 \mathrm{~min}$ for liver and $20 \mathrm{~min}$ for brain homogenates. The extinction was read at $490 \mathrm{~m} \mu$ with a Beckman $1 \mathrm{U}$ U spectrophotometer. All determinations were run in duplicate or triplicate together with the necessary standards and blanks. The determinations were made at the same time with one cold acclimatized and one control animal. The mean results with their standard errors are presented below. The number of animals is shown in brackets.

The enzyme activities are higher in the liver and lower in the brain of mice than those found in the corresponding tissues of rats with the same technique ${ }^{3}$. The succinic dehydrogenase activity is $72 \%$ higher in the animals

1 J.S. HaRT, Brit. Med. Bull. Ir, 19 (1961). - F. Depocas, Brit. Mad. 13u1l. 17,25 (1961).

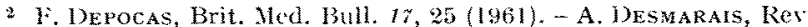
Canad. Biol. 13, 115 (1954). - J. P. Hannon, Amer. J. Physiol. 198, $7.10(1960)$. - R. W. You and E. A. SELLERs, Endocrinology 49, 374 (1951).

3 Ji. Kun and L. G. Aroon, Science 109,144 (1949). 